UDC $613 ; 614$

DOI: $10.21668 /$ health.risk/2020.1.01.eng

\title{
SOCIAL AND EPIDEMIOLOGIC DETERMINANTS AND POTENTIAL FOR GROWTH IN LIFE EXPECTANCY OF THE POPULATION IN THE RUSSIAN FEDERATION TAKING INTO ACCOUNT REGIONAL DIFFERENTIATION
}

\author{
A.Yu. Popova ${ }^{1,2}$, N.V. Zaitseva ${ }^{3,4}$, G.G. Onishchenko ${ }^{4,5}$, \\ S.V. Kleyn ${ }^{3,6}$, M.V. Glukhikh ${ }^{3}$, M.R. Kamaltdinov ${ }^{3}$ \\ ${ }^{1}$ Federal Service for Surveillance on Consumer Rights Protection and Human Wellbeing, Bld. 5 and 7, \\ 18 Vadkovskiy lane, Moscow, 127994, Russian Federation \\ ${ }^{2}$ Russian Medical Academy for Postgraduate Studies, 2/1 Barrikadnaya Str., Moscow, 123995, Russian Federation \\ ${ }^{3}$ Federal Scientific Center for Medical and Preventive Health Risk Management Technologies, 82 Monastyrskaya \\ Str., Perm, 614045, Russian Federation \\ ${ }^{4}$ Russian Academy of Science, 32 Leninskii Ave., Moscow, 119334, Russian Federation \\ ${ }^{5}$ I.M. Sechenov First Moscow State Medical University, Bld. 2, 2 Bol'shaya Pirogovskaya Str., Moscow, 119435, \\ Russian Federation \\ ${ }^{6}$ Perm State University, 15 Bukireva Str., Perm, 614990, Russian Federation
}

The current work supplements the results obtained in previous research on a relation between leading parameters of living conditions and life expectancy of the $R F$ population; it dwells on the results obtained via analyzing a role played by sanitary and epidemiologic determinants. A sanitary-epidemiologic situation in certain $R F$ regions is unfavorable and it makes our research truly vital; it is also necessary to work out and implement activities aimed at eliminating or minimizing adverse environmental factors that can produce negative effects on demographic situation in the country. Our primary goal was to study impacts exerted by sanitary-epidemiologic parameters on life expectancy in the RF and to obtain predicted values for its growth taking into account regional and sex differentiation.

We examined domestic and foreign experience in researching relations between sanitary-epidemiologic welfare and life expectancy. All the RF regions were distributed into three clusters as per their sanitary-epidemiologic welfare. The third cluster that includes 11 regions is in much greater need for implementing activities aimed at reducing environmental contamination. Results obtained via regression and factor analysis revealed that should there be a scenario with an improvement in sanitary-epidemiologic parameters (by $10.0 \%$ ), the overall life expectancy for the RF population would increase by 140.39 days. An improvement in sanitary-epidemiologic situation taken as per sex differentiation indicated that a greater impact was expected on life expectancy growth among male population, as it would increase by 146.9 days (by 117.6 days for female population). We established that several parameters made the greatest contribution into life expectancy growth; they were "A share of population provided with high quality drinking water" (61.65 days); "Physical factors existing at workplaces" (35.83 days), "Sanitary-hygienic characteristics of objects under surveillance" (15.16 days), and "Sanitary-epidemiologic parameters of ambient air" (14.26 days).

The current work does not cover extreme sanitary-epidemiologic situations related to pandemic spread of new infectious agents causing highly contagious diseases (Coronavirus infection).

Key words: life expectancy, sanitary-epidemiologic factors, environment, demographic policy, population, life quality, factor analysis, cluster analysis.

(C) Popova A.Yu., Zaitseva N.V., Onishchenko G.G., Kleyn S.V., Glukhikh M.V., Kamaltdinov M.R., 2020

Anna Yu. Popova - Doctor of Medical Sciences, Professor, Supervisor, Head of the Department for Sanitary-Epidemiologic Service Organization (e-mail: rmapo@rmapo.ru; tel.: +7 (499) 458-95-63; ORCID: https://orcid.org/0000-0002-4315-5307).

Nina V. Zaitseva - Academician of the Russian Academy of Sciences, Doctor of Medical Sciences, Professor, Scientific Director (e-mail: znv@fcrisk.ru; tel.: +7 (342) 237-25-34; ORCID: https://orcid.org/0000-0003-2356-1145).

Gennadiy G. Onishchenko - The RAS Academician, Doctor of Medical Sciences, Professor, Head of the Department for Human Ecology and Environmental Hygiene (e-mail: journal@fcrisk.ru; tel.: +7 (495) 954-39-85; ORCID: http://orcid.org/0000-0003-0135-7258).

Svetlana V. Kleyn - Doctor of Medical Sciences, Associate Professor, Head of the Department for Systemic Procedures of Sanitary-Hygienic Analysis and Monitoring (e-mail: kleyn@fcrisk.ru; tel.: +7 (342) 237-18-04; ORCID: https://orcid.org/0000-0002-2534-5713).

Maksim V. Glukhikh - Post-graduate student, Junior researcher (e-mail: gluhih@fcrisk.ru; tel.: +7 (342) 237-18-04; ORCID: https://orcid.org/0000-0002-4755-8306).

Marat R. Kamaltdinov - Candidate of Physical and Mathematical Sciences, Senior researcher acting as the Head of the Department for Situation Modeling and Expert and Analytical Management Techniques Laboratory (e-mail: kmr@fcrisk.ru; tel.: +7 (342) 237-18-04; ORCID: http://orcid.org/0000-0003-0969-9252). 
Introduction. In the $2^{\text {nd }}$ half of the $20^{\text {th }}$ century efforts made by the whole mankind allowed minimizing (variola eradication and elimination of measles, rubella, and poliomyelitis on certain territories) and almost completely getting rid of known communicable diseases; it resulted in the most favorable situation in public healthcare in history $[1,2]$. During that period life span and life expectancy of a human being as a biological species achieved their record length and it is confirmed by mortality curve becoming rectangular [3-5]. Successes achieved in struggling against communicable diseases allowed decreasing their influence on public health as well as prolong life expectancy; but at the same time it led to changes in structure of morbidity and mortality. Nowadays noncommunicable diseases (NCDs) are the leading cause of deaths all ever the world and in the Russian Federation (RF) as well [6]. Besides, such a wide spread of these diseases to a greater extent is determined by impacts exerted by scientific and technological progress on the environment and people.

Technological progress resulted in two most significant and interrelated processes in the society, namely industrialization and urbanization. Industrialization allowed significant increase in social and economic welfare of the population thus stimulating further society development. A change in social and economic relations led to a natural transition from a predominantly traditional (agricultural) society to a contemporary (urbanized) one with its peculiarities, including deteriorating ecological conditions in settlements due to intensifying industrial activities and growing transport flows. All the described processes are apparent in developing countries, such as China, India, or Pakistan [7-10].

Anthropogenic activities resulted in greater technogenic loads on the environment, namely great quantities of contaminants accumulated in environmental objects as well as wider spread of certain physical factors such as noise, vibration, electromagnetic irradiation, etc. [11-13].
As per WHO data, a contribution made by environmental factors may well reach $25.0 \%$. Despite several research works [14-17] stating that lifestyle and living standards of people exert more substantial influence on diseases occurrence and clinical course, qualitative properties of the environment where these people live can either make for deterioration of their health or, on the contrary, can be a source for its recovery and improvement via recreational opportunities or possibility to get good rest on a specific territory.

Drinking water sources, together with ambient air and soils, are gravely contaminated due to anthropogenic activities. Primary contaminants in water are heavy metals, microbiological agents, emergent contaminants, and other chemicals that penetrate water with sewage discharges from industrial and communal objects, diffusely enter from soils cultivated by agricultural enterprises, or from precipitations. We should take into account that new chemical compounds that can be found in drinking water sources occur faster than any potential hazardous effects produced by them on a human body are determined and that water is often supplied to an end customer via old water supply systems, and it, in one way or another, results in urban population facing a problem related to drinking water contamination $[18,19]$.

Existing water treatment facilities are able to prevent acute intoxications caused by drinking water contamination; however, the above mentioned factors gradually increase probability of various diseases such as urolithiasis and oncologic diseases and in case of any emergencies even communicable diseases [20-22].

About $90.0 \%$ people are exposed to ambient air that doesn't conform to the WHO requirements regarding ambient air quality ${ }^{1}$. As per data provided by Global Health Observatory (GHO/WHO) [23] in 2016 approximately 7 million deaths all over the world were caused by ambient air contamination (4.2 million deaths) and contaminated air inside premises; ambient air contamination accounts for approximately $25.0 \%$ deaths due to ischemic

\footnotetext{
${ }^{1}$ WHO recommendations fix average annual limit for $\mathrm{PM}_{2.5}$ particles amounting to $10 \mu \mathrm{g} / \mathrm{m}^{3}$.
} 
heart disease and $24.0 \%$ deaths due to cardiac infarction as well as about 246,000 deaths of children younger than 5 [24]. As per research data, in the RF overall number of deaths caused by exposure to particulate matter $\left(\mathrm{PM}_{10}{ }^{2}\right.$; $\mathrm{PM}_{2.5}$ ) amounted to 140,851 cases among people of both sexes (UI': 59,079-192,348), 83,938 out of them being due to ischemic heart disease, and 46,216 due to cardiac infarction. This quantity of death cases related to particulate matter contents in ambient air is one of the highest in the world as higher figures are registered only in India, 621,138 death cases (UI: 515,242-744,416), and China, 1,032,833 death cases (UI: 869,033-1,212,034) [25].

Environmental contamination leads to substantial losses in the world economy as well as certain national economies. Data provided by the Global Commission on Pollution and Health indicate that there are $2.0 \%$ losses in GDP in middle-income countries (MIC) and low-income countries (LIC) due to diseases caused by environmental contamination. Besides, there is a growth in annual expenses on public healthcare that varies from $1.7 \%$ in high-income countries (HIC) and up to $7.0 \%$ in MIC and LIC where industrialization and urbanization are developing more intensely at the moment. Overall world economic losses caused by environmental contamination are 4.6 trillion USD [26].

As per data provided by S.A. Sarkodie et al., a growth in industrial emissions that contain $\mathrm{PM}_{2.5}$ results in $0.004 \%$ decrease in life expectancy (LE) $\left(\mathrm{CI}^{4}: 95.0 \%\right)$ [27]. The author also showed in that work that an increase in incomes as a process which was closely connected with growing environmental contamination led to a $0.02 \%$ increase in LE (CI: 95,0\%) and a $0.01 \%$ decrease in overall mortality. This phenomenon is explained with a hypothesis known as the Environmental Kuznets Curve [28]. According to this hypothesis a relation between the parameters is an upturned $U$ and it shows that growing incomes go together with growing environmental contamination; however, in fu- ture, after certain population welfare has been reached, a society starts to implement activities aimed at reducing anthropogenic loads on the environment (ecological taxes, hygienic standards, transition to ecologically friendly technologies in energy production and manufacturing). A similar research work accomplished in the USA revealed that, firstly, there was an inverse correlation between LE and ambient air contamination with particulate matter; and, secondly, the correlation became even stronger in case there was inequality in population incomes [29].

As per data obtained by researchers from Denmark, life expectancy goes down not only due to ambient air being contaminated with ultra-dispersed particles, but also with nitrogen dioxide emitted by transport. Should $\mathrm{NO}_{2}$ emissions from transport decrease up to levels that are typical for rural areas or by $20.0 \%$, it will result in LE increase by 2040 in Denmark, by 2.0 and 0.6 years for men and by 0.4 and 0.1 years for women accordingly [30].

Employable people are exposed to occupational factors during the biggest part of their lives. Impacts exerted by various occupational factors (chemical, physical, or biological ones) can lead to deterioration in one's health; various occupational pathologies, either mild or grave; a decrease in workers' life span; more frequent oncologic diseases; deterioration in emotional and mental state caused by various factors; as well as to other disorders [31-36].

In 2015 The UN General Assembly approved on a program called Sustainable Development Goals; it contains 17 global goals that the mankind is to achieve in order to support sustainable development up to 2030 . The program describes urgent issues existing in the world in great detail; these issues are to be resolved in the next two decades. The program also sets certain tasks which are to be solved for achieving these goals. A pressing issue in public healthcare is to reduce mortality caused by NCDs by third; tasks which are to be

\footnotetext{
${ }^{2}$ Particulate matter (PM) are solid particles with their diameter being less than $10.0 \mathrm{~nm}$ and $2.5 \mu \mathrm{m}$.

${ }^{3}$ Uncertainty Interval.

${ }^{4} \mathrm{CI}$ means confidence interval.
} 
solved in the sphere involve reducing mortality and morbidity due to effects produced by hazardous chemicals and environmental contamination. Key instruments here are early prevention of hazardous effects on health and relevant policy aimed at reducing population health risks. Tasks in the sphere of ecology and environmental protection involve transition to ecologically friendly power production as well as rational use of chemicals and wastes together with a reduction in their volumes that penetrate the environment ${ }^{5}$.

Despite the Russian Federation being among countries with high incomes (HIC), life expectancy in our country is significantly lower than in other economically developed countries. According to official statistic data, in 2018 life expectancy in Russia amounted to 72.91 years while in other European countries it was equal to 80 years or even more ${ }^{6}$. An important role here belongs to quantity of people exposed to negative impacts exerted by environmental factors. Data obtained via social and hygienic monitoring in 2018 revealed that more than $62 \% \mathrm{RF}$ population were exposed to adverse effects produced by contaminated drinking water, ambient air, and soils as well as to hazardous physical factors ${ }^{7}$.

Taking into account world trends in environmental protection as well as specific demographic situation in the Russian Federation, state authorities have developed and are now implementing such national projects as "Demography" "Public healthcare", and "Ecology" which are aimed at preserving and multiplying human capital as well as creating a comfortable environment for country population [37].

Our research goal was to study sanitary and epidemiologic determinants and related potential for a growth in life expectancy in the Russian Federation.

Data and methods. This research work continues studying relations between environmental factors and life expectancy in the RF.
To gain comparable results, just as it was the case with the first research work [8] that dwelled on impacts exerted on life expectancy for the whole country population by social and economic factors, we applied the same methodical approach in the present work. A basic distinction is that this study focuses on other influencing determinants or sanitary and epidemiologic parameters. We put forward a hypothesis that there is a direct or inverse regular causeand-effect relation between life expectancy at birth (overall population, men and women separately, dependent variables) and sanitary-epidemiologic determinants (risk factors or independent variables, predictors or regressors).

Our analysis and model creation was based on statistical data collected in 2010-2018 in $85 \mathrm{RF}$ regions (and data for the whole country) which were obtained from official sources such as reports issued by the Federal Statistics Service (emissions from stationary an mobile sources, life expectancy); Reports as per N 18 Statistic Form "Data on sanitary situation in a region in the RF" (sanitary-epidemiologic parameters).

Overall, we included 111 sanitary-epidemiologic parameters in our research. They were distributed into several groups according to sections in Statistic Form N 18: situation with drinking water supply; data on population being provided with drinking water that conformed to safety standards; a situation with water objects which people used to obtain water; ambient air contamination; situation with soils; hygienic properties of raw materials and food products; air inside premises and in working areas; a study on physical factors; sanitary-hygienic properties of objects applied by economic agents under surveillance in their activities.

We took Statistica 10.0 software for statistic analysis as our basic tool for testing adequacy and calculating parameters included into obtained models. Statistical hypotheses were

\footnotetext{
${ }^{5}$ Sustainable development goals. The United Nations Organization. Available at: https://www.un.org/sustainabledevelopment/ru/sustainable-development-goals/ (22.01.2020).

${ }^{6}$ Russian Regions. Social and economic parameters. 2019: P32 Statistic data collection. Rosstat. Moscow, 2019, vol. 1, 204 p.

${ }^{7}$ On sanitary-epidemiologic welfare of the population in the Russian Federation in 2018: The State report. Moscow, The Federal Service for Surveillance over Consumer Rights Protection and Human Well-being, 2019, 254 p.
} 
checked against regression quotients with Student's t-test in case parameters distribution was normal. Models were checked for their adequacy via dispersion analysis with Fischer's test and significance level being 0.05 .

We applied factor analysis to solve tasks related to studying multiple correlations between sanitary-epidemiologic parameters and LEB as well as to reduce initial data dimension. Statistical models for correlations were built as per the following chain: "sanitaryepidemiologic parameters - generalized factors - life expectancy". We applied Kaiser Criterion (eigenvalues criterion) to reduce a number of common factors obtained via sequential building of correlation variables matrix with subsequent factors extraction with the least square technique. It allowed us to reduce a number of common factors to 12 . Mutual influence exerted by factors on each other was excluded via orthogonal radiation with obtaining values for loads of variables on factors. These approaches allowed calculating quantitative changes in LEB under preset changes in examined sanitary-epidemiologic parameters.

An algorithm for building cause-and-effects relations as per "sanitary-epidemiologic parameters - generalized factors - life expectancy" chain included the following basic stages:

- recovering data for specific data series as per an algorithm that is given below;

- calculating mean values of a parameter and standard deviation for observation series;

- setting predicted sanitary-epidemiologic parameters via making changes into initial values by a scenario per cent (for example, $10 \%$, $5 \%$, or $1 \%$ );

- calculating a difference between predicted and actual value of a sanitary-epidemiologic parameter;

- calculating standardized difference between predicted and actual value of a sanitaryepidemiologic parameter;

- calculating changes in generalized factors associated with changes in a sanitaryepidemiologic parameter, taking into account multiple regression coefficient "sanitaryepidemiologic parameters - life expectancy";

- ranking all the sanitary-epidemiologic parameters as per their contributions made into changes in LEB;
- summing up all the values of changes in LEB obtained at the previous stage associated with changes in a sanitary-epidemiologic parameter.

The difference between predicted and actual values of a sanitary-epidemiologic parameter was calculated as per the formula (1):

$$
\Delta D=D^{\prime}-D
$$

where $\Delta D$ is the difference between a predicted value of a sanitary-epidemiologic parameter $\left(D^{\prime}\right)$ and its actual value $(D)$.

Standardized difference between a predicted and an actual value of a parameter was determined as per the following formula (2):

$$
\begin{gathered}
\Delta d=d^{\prime}-d=\frac{D^{\prime}-\bar{D}}{D_{s}}-\frac{D-\bar{D}}{D_{s}}= \\
=\frac{D^{\prime}-D}{D_{s}}=\frac{\Delta D}{D_{s}},
\end{gathered}
$$

where $\Delta d$ is the standardized difference between a predicted and an actual value of a parameter; $d^{\prime}$ is a standardized predicted value of a parameter; $\mathrm{d}$ is a standardized actual value of a parameter; $\bar{D}$ is an average value of a parameter with recovered data; $D_{s}$ is a standard deviation in a parameter with recovered data.

We calculated changes in generalized factors associated with changes in a sanitaryepidemiologic parameter as per the following formula (3):

$$
\Delta F_{i}=\Delta d \cdot k_{i}
$$

where $\Delta F_{i}$ is a change in the $i$-th generalized factor associated with a change in a sanitaryepidemiologic parameter; $k_{i}$ is a factor coefficient for the $i$-th generalized factor (determined as per factor analysis results).

A change in life expectancy associated with a change in a sanitary-epidemiologic parameter was determined via summing up all the products of changes in generalized factors multiplied by relevant "sanitary-epidemiologic parameters - LEB" multiple regression coefficients as per the following formula (4):

$$
\Delta Z=\Delta F_{i} \cdot b_{i},
$$


where $\Delta Z$ is a change in life expectancy associated with a change in a sanitary-epidemiologic parameter given in years; $b_{i}$ is a coefficient before the $i$-th factor in "sanitary-epidemiologic factors - LEB" multiple regression.

Exploratory factor analysis allowed obtaining a factor burden matrix that totally included 12 factors. Cumulative per cent of explained variance gained from these 12 factors amounted to $68.73 \%$. Formulas (3) and (4) were applied to calculate quantitative changes in LEB associated with a change in each examined sanitaryepidemiologic parameter. We give an example of calculating a change in life expectancy depending on a $10.0 \%$ change in values of sanitary-epidemiologic parameters; in this calculation parameters that led to an increase in LEB were raised by $10.0 \%$, and those that decreased LEB were reduced by $10.0 \%$.

We divided RF regions into several clusters according to their sanitary-epidemiologic parameters and LEB applying a multi-dimensional statistical procedure, namely cluster analysis with k-medians clustering. Parameter values in clusters were compared as per their average cluster values.

Results and discussion. Linear correlation-regression analysis allowed us to obtain 195 authentically significant models and 134 out of them didn't contradict the hypothesis on cause-and-effect relations between population health and a sanitary-epidemiologic situation with environmental factors. We analyzed a correlation between sanitary-epidemiologic parameters and LEB of overall population and revealed the most significant factors as per explained variance coefficient $\left(\mathrm{R}^{2}\right)$; these factors given in the descending order are as follows: "A share of workplaces not conforming to sanitary standards as per illumination" $\left(\mathrm{a}_{\mathrm{x}}=-0.239\right.$; $\left.\mathrm{b}=72.59 ; \mathrm{p}<0.05 ; \mathrm{r}=-0.495 ; \mathrm{R}^{2}=0.245\right)$; "A share of workplaces not conforming to sanitary standards as per microclimate" $\left(\mathrm{a}_{\mathrm{x}}=-0.195\right.$; $\left.\mathrm{b}=71.68 ; \mathrm{p}<0.05 ; \mathrm{r}=-0.473 ; \mathrm{R}^{2}=0.224\right)$; "A share of workplaces not conforming to sanitary standards as per noise" $\left(\mathrm{a}_{\mathrm{x}}=-0.105\right.$; $\left.\mathrm{b}=71.98 ; \mathrm{p}<0.05 ; \mathrm{r}=-0.367 ; \mathrm{R}^{2}=0.135\right)$; "A share of air samples with dust and aerosol contents exceeding $\operatorname{MPC}^{8,} \quad\left(\mathrm{a}_{\mathrm{x}}=-0.158\right.$; $\left.\mathrm{b}=71.27 ; \mathrm{p}<0.05 ; \mathrm{r}=-0.35 ; \mathrm{R}^{2}=0.122\right)$.

The most significant parameters for LE among male population were the following: "A share of workplaces not conforming to sanitary standards as per illumination" $\left(\mathrm{a}_{\mathrm{x}}=-0.262\right.$; $\left.\mathrm{b}=67.25 ; \mathrm{p}<0.05 ; \mathrm{r}=-0.468 ; \mathrm{R}^{2}=0.219\right)$; "A share of workplaces not conforming to sanitary standards as per microclimate" $\left(\mathrm{a}_{\mathrm{x}}=-0.201\right.$; $\left.\mathrm{b}=66.17 ; \mathrm{p}<0.05 ; \mathrm{r}=-0.423 ; \mathrm{R}^{2}=0.179\right)$; "A share of workplaces not conforming to sanitary standards as per noise" $\left(\mathrm{a}_{\mathrm{x}}=-0.119\right.$; $\left.\mathrm{b}=66.66 ; \mathrm{p}<0.05 ; \mathrm{r}=-0.362 ; \mathrm{R}^{2}=0.131\right)$; "A share of air samples with contents of substanes belonging to the $1^{\text {st }}$ and $2^{\text {nd }}$ hazard category exceeding MPC (vapor and gases)" $\left(\mathrm{a}_{\mathrm{x}}=-0.231\right.$; $\left.\mathrm{b}=65.43 ; \mathrm{p}<0.05 ; \mathrm{r}=-0.33 ; \mathrm{R}^{2}=0.109\right)$.

The most significant parameters for LE among female population were the following: "A share of workplaces not conforming to sanitary standards as per illumination" $\left(\mathrm{a}_{\mathrm{x}}=-0.202\right.$; $\left.\mathrm{b}=77.79 ; \quad \mathrm{p}<0.05 ; \quad \mathrm{r}=-0.51 ; \quad \mathrm{R}^{2}=0.261\right)$; "A hare of workplaces not conforming to sanitary standards as per microclimate" $\left(\mathrm{a}_{\mathrm{x}}=-0.171\right.$; $\left.\mathrm{b}=77.08 ; \mathrm{p}<0.05 ; \mathrm{r}=-0.511 ; \mathrm{R}^{2}=0.261\right)$; A hare of air samples with dust and aerosol contents exceeding MPC $\left(a_{x}=-0.134 ; b=76.73\right.$; $\left.\mathrm{p}<0.05 ; \mathrm{r}=-0.37 ; \mathrm{R}^{2}=0.137\right)$; "A share of workplaces not conforming to sanitary standards as per noise" $\left(\mathrm{a}_{\mathrm{x}}=-0.082 ; \mathrm{b}=77.17\right.$; $\mathrm{p}<0.05 ; \mathrm{r}=-0.35 ; \mathrm{R}^{2}=0.123$ ).

As per cluster analysis results, all the RF regions were distributed into 3 clusters, each having its peculiarities related to a sanitaryepidemiologic situation there. The $1^{\text {st }}$ cluster included 24 regions; the $2^{\text {nd }}, 50$ regions; the $3^{\text {rd }}, 11$ regions (Figure 1 ).

The 1st cluster includes $24 \mathrm{RF}$ regions, namely Belgorod, Bryansk, Vladimir, Ivanovo, Kaluga, Kostroma, Smolensk, Tambov, Tula, Yaroslavl, Arkhangelsk, Leningrad, Murmansk, Rostov, Kirov, Samara, Ulyanovsk, Sverdlovsk, Chelyabinsk, and Magadan regions, the Nenets Autonomous Area, Mordovia, Primorye, and the Jewish Autonomous Region. Average cluster LE value for the overall population amounted to 71.8 years; male population, 66.4 ears (the lowest LE among all clusters);

${ }^{8}$ MPC means maximum permissible concentration. 
female population, 77.1 years. Drinking water supply was analyzed and assessed as per a share of samples not conforming to requirements as per sanitary-chemical properties; those shares amounted to $24.3 \%$ for centralized water supply networks and to $18.8 \%$ for distribution networks thus making average cluster values higher than in the country on average (16.97\% and $13.0 \%$ accordingly). A share of air samples with MPC deviating from standards in urban settlements was the lowest among all three clusters $(0.56 \%)$. Sanitary-epidemiologic situation with soil in regions belonging to the $1^{\text {st }}$ cluster is relatively unfavorable (certain parameters being higher than in the country on average): a share of soils samples not conforming to standards as per sanitarychemical parameters amounts to $7.98 \%$, including those as per metals, $7.97 \%$; a share of soil samples deviating from standards as per microbiological parameters amounts to $9.98 \%$ (the highest value among all three clusters). Parameters related to food products safety and quality also deviated from standards more frequently in this cluster than in the country on average. Thus, a share of samples not conforming to requirements as per sanitary-epidemiologic parameters amounts to $0.45 \%(0.39 \%$ on average in the $\mathrm{RF}$ ); as per microbiological parameters, $4.25 \%$
( $3.88 \%$ on average in the RF); a share of samples not corresponding to standards as per calorie contents and chemical structure amounts to $9.75 \%(6.73 \%$ on average in the RF). Certain parameters of air in working areas at economic entities operating in regions form the $1^{\text {st }}$ cluster are also higher than in the country on average; a share of air samples with vapor and gases contents exceeding MPC amounts to $1.44 \%$ ( $1.38 \%$ on average in the RF), and a share of air samples with contents of substances belonging to the $1^{\text {st }}$ and $2^{\text {nd }}$ hazard category exceeding MPC (vapor and gases) amounts to $1.9 \%$ ( $1.77 \%$ on average in the RF). Workplaces were assessed as per physical factors occurring there; the assessment revealed that the cluster had the highest share of samples deviating from standards as per "IR" share of deviating samples as per "noise" factors amounted to $13.86 \%$; "microclimate", $5.22 \%$; "EMF" ${ }^{10 ",} 5.87 \%$, "illumination", $8.76 \%$; all these values are higher than on average in the country $(12.76 \%, 4.7 \%, 4.49 \%$, and $8.31 \%$ accordingly). The cluster also has the lowest share of objects belonging to the $3^{\text {rd }}$ hazard category as per their sanitary-hygienic characteristics $(3.01 \%)$; a share of objects belonging to the $1^{\text {st }}$ category amounts to $48.1 \%$.

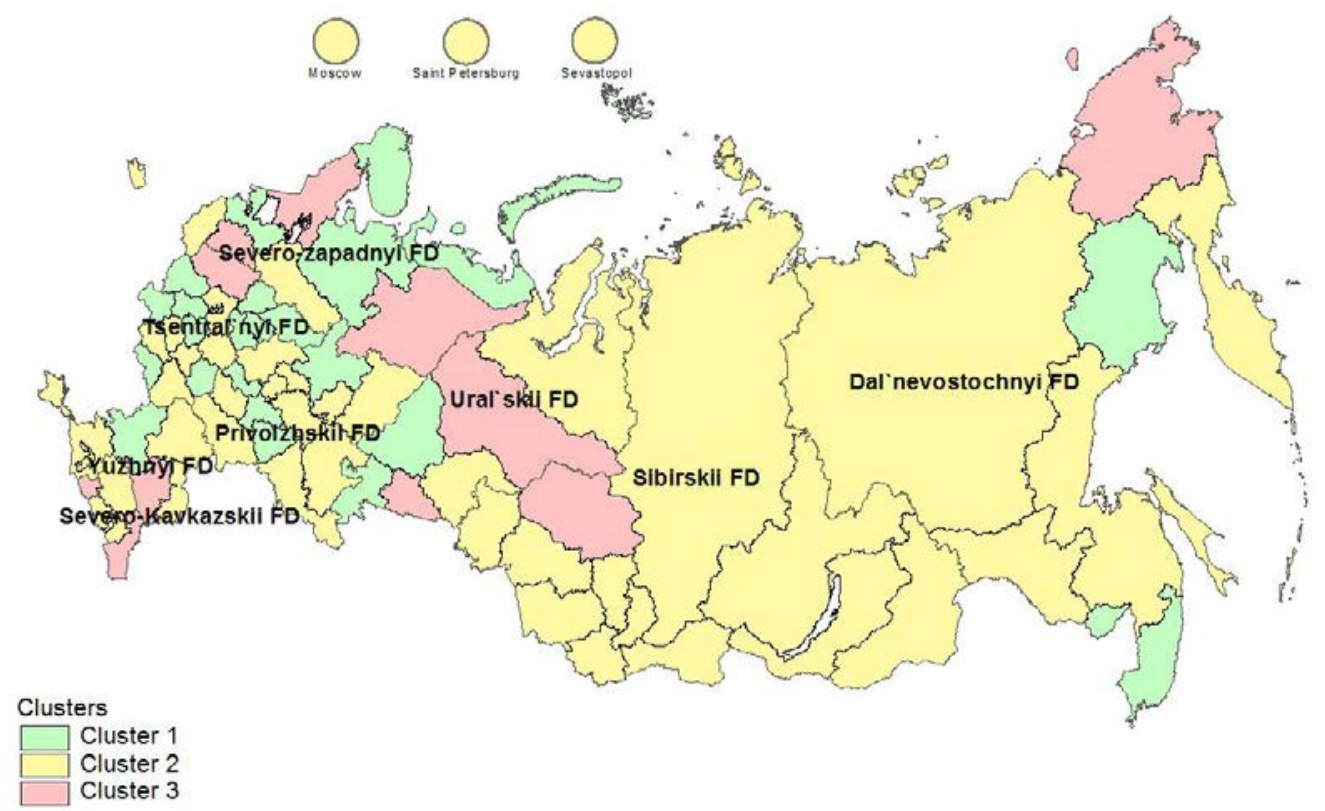

Figure 1. RF regions distributed into 3 clusters as per sanitary-epidemiologic parameters

\footnotetext{
${ }^{9}$ IR means ionizing radiation.

${ }^{10} \mathrm{EMF}$ - Electromagnetic fields.
} 
The $2^{\text {nd }}$ cluster includes $50 \mathrm{RF}$ regions, namely Voronezh, Kursk, Lipetsk, Moscow, Orel, Ryazan, Vologda, Kaliningrad, Pskov, Astrakhan, Volgograd, Nizhniy Novgorod, Orenburg, Penza, Saratov, Tyumen, Irkutsk, Kemerovo, Novosibirsk, Omsk, Amur, Sakhalin, Moscow City, Saint Petersburg, Adygei Republic, Crimea, Krasnodar, Sevastopol, Ingushetia, Kabardino-Balkarskaya Republic, North Ossetia, Chechnya, Stavropol, Bashkortostan, Mari El Republic, Tatarstan, Udmurtia, Chuvashskaya Republic, Perm region, YamalNenets Autonomous Area, Altai Republic, Buryatia, Tyva Republic, Khakassia, Altai region, Transbaikalia, Krasnoyarsk, Yakut Republic, Kamchatka, and Khabarovsk region. This cluster has LE comparable with average Russian one for the overall population, male and female population as well $(72.46,67.29$, and 77.45 years accordingly). Drinking water quality in this sector is better than on average in the country; a share of samples from supply and distribution networks that deviate from standards as per sanitary-chemical parameters amounts to $9.79 \%(16.97 \%$ on average in the RF) and $9.81 \%(9.81 \%$ on average in the RF). Sanitary-epidemiologic situation with soils in regions in this cluster is also comparatively better than on average in the country; a share of soil samples deviating from standards as per sanitary-chemical parameters amounts to $4.75 \%$ (5.06\% on average in the country); as per microbiological parameters, $5.95 \%$ (5.95\% on average in the country). A situation with food products safety and quality is also quite favorable in the cluster as a share of samples not conforming to standards as per microbiological parameters amounts to $3.66 \%$; a share of samples not conforming to standards as per calorie contents and chemical structure amounts to $6.08 \%$; a share of samples deviating from standards as per sanitary-chemical parameters amounts to $0.41 \%$; all these values are close to average country levels $(3.88 \%, 6.73 \%$, and $0.39 \%$ accordingly). Quality of air in working areas at economic entities operating in the cluster is the highest among all three clusters as per a share of air samples with dust and aerosol contents exceeding MPC (3.52\%) and a share of air samples with contents of substances belonging to the $1^{\text {st }}$ and $2^{\text {nd }}$ hazard category exceeding MPC (dust and aerosols) $(2.91 \%)$. The cluster has the lowest number of workplaces that don't conform to sanitary standards as per physical factors; as per noise, $9.57 \%$; vibration, $4.04 \%$; microclimate, $4.09 \%$; EMF, $2.93 \%$; illumination, $7.19 \%$; IR, $0.4 \%$.

The $3^{\text {rd }}$ cluster includes $11 \mathrm{RF}$ regions, namely Tver, Novgorod, Kurgan, Tomsk, Karelia, the Komi Republic, the Kalmyk Republic, Dagestan, Karachai-Cherkess, KhantiMansi Autonomous Area, and Chukotka. LE among the overall population and female population is the lowest here against the other two clusters (71.6 and 76.6 years accordingly). Quality of drinking water taken from centralized water supply systems in unsatisfactory as a share of water samples that deviate from standards as per sanitary-chemical parameters amounts to $44.6 \%$ for water taken from water supply systems and to $36.6 \%$ for water taken from distribution networks. There are similar problems with ambient air quality as a share of ambient air samples with exceeding MPC amounted to $3.92 \%$ in urban settlements $(0.66 \%$ on average in the RF). But soil quality, on the contrary, is the highest in this cluster as a share of soil samples that deviate from standards as per sanitary-chemical parameters amounts to $4.38 \%(2.99 \%$ as per metals $)$. Food products safety and quality is in general lower than on average in the country. A share of food products samples that don't conform to sanitary-epidemiologic requirements as per sanitary-chemical parameters amounts to $0.77 \%(0.39 \%$ on average in the RF $)$. Certain food products have the lowest quality as per this parameter, for example, poultry and poultry products $(0.17 \%)$; butter and butter products $(0.26 \%)$; fish and fish products $(2.21 \%)$; culinary products $(0.65 \%)$ : vegetables and greenery $(1.51 \%)$. A share of workplaces that don't correspond to sanitary standards as per vibration and microclimate is also the highest in the cluster $(10.83 \%$ and $12.62 \%$ accordingly). A share of objects that belong to the $1^{\text {st }}$ hazard category as per their sanitaryhygienic properties is the lowest in this clus- 
ter $(35.61 \%)$; and a share of objects belonging to the $3^{\text {rd }}$ hazard category is the highest $(5.9 \%)$.

Factor analysis results allowed us to establish predicted values of life expectancy at birth (overall population; make and female population separately) that are related to sanitary-epidemiologic parameters. Table contains LEB values under a scenario with a $10 \%$ improvement in the given parameters.

Table

Potential growth (in days) in life expectancy of the RF population related to changes in sanitary-epidemiologic parameters (a scenario entails a $10.0 \%$ improvement in the given parameters)

\begin{tabular}{|c|c|c|c|c|}
\hline $\begin{array}{l}\text { A group } \\
\text { of parameters }\end{array}$ & Parameter & $\begin{array}{c}\text { An increase in } \\
\text { LEB (overall } \\
\text { population) } \\
\text { days }\end{array}$ & \begin{tabular}{|c|} 
An increase \\
in LEB (male \\
population), \\
days
\end{tabular} & $\begin{array}{l}\text { An increase } \\
\text { in LEB } \\
\text { (female popula- } \\
\text { tion), days }\end{array}$ \\
\hline \multirow{4}{*}{$\begin{array}{l}\text { Sanitary-epide- } \\
\text { miologic parame- } \\
\text { ters related to am- } \\
\text { bient air quality }\end{array}$} & $\begin{array}{l}\text { A share of ambient air samples with contami- } \\
\text { nants contents being higher than MPC (in } \\
\text { urban settlements) }\end{array}$ & 0.71 & 0.39 & 0.38 \\
\hline & $\begin{array}{l}\text { Mobile monitoring posts. A share of ambient } \\
\text { air samples with contaminants contents being } \\
\text { higher than MPC (in urban settlements) }\end{array}$ & 6.16 & 5.98 & 5.98 \\
\hline & $\begin{array}{l}\text { Observations at stationary posts. A share of } \\
\text { ambient air samples with contaminants con- } \\
\text { tents being higher than MPC (in urban settle- } \\
\text { ments) }\end{array}$ & 3.92 & - & 4.19 \\
\hline & $\begin{array}{l}\text { A share of ambient air samples with contami- } \\
\text { nants contents being higher than MPC (in } \\
\text { rural settlements) }\end{array}$ & 3.47 & 3.64 & 3.64 \\
\hline \multicolumn{2}{|c|}{$\begin{array}{l}\text { A parameters showing sanitary-epidemiologic situation with } \\
\text { drinking water - a share of population provided with qualitative } \\
\text { drinking water }\end{array}$} & 61.65 & 74.71 & 37.83 \\
\hline \multirow{3}{*}{$\begin{array}{l}\text { Sanitary- } \\
\text { epidemiologic } \\
\text { parameters related } \\
\text { to soil quality }\end{array}$} & $\begin{array}{l}\text { A share of samples not conforming to SER* } \\
\text { (microbiological parameters) }\end{array}$ & 4.04 & 5.95 & 2.66 \\
\hline & $\begin{array}{l}\text { A share of samples not conforming to SER } \\
\text { (sanitary-chemical parameters) }\end{array}$ & 1.05 & 1.53 & 0.58 \\
\hline & $\begin{array}{l}\text { A share of samples not conforming to SER } \\
\text { (sanitary-chemical parameters. Metals) }\end{array}$ & 0.73 & 1.08 & 0.45 \\
\hline \multirow{7}{*}{$\begin{array}{l}\text { Parameters related } \\
\text { to food products } \\
\text { quality and safety }\end{array}$} & $\begin{array}{l}\text { All food products. A share of samples not } \\
\text { conforming to SER (sanitary-chemical pa- } \\
\text { rameters) }\end{array}$ & 0.44 & 0.46 & 0.24 \\
\hline & $\begin{array}{l}\text { Fish. A share of samples not conforming to } \\
\text { SER (parasitological parameters) }\end{array}$ & 0.24 & 0.21 & 0.37 \\
\hline & $\begin{array}{l}\text { Vegetables. Greenery. A share of samples not } \\
\text { conforming to SER (sanitary-chemical pa- } \\
\text { rameters) }\end{array}$ & 0.22 & 0.06 & 0.09 \\
\hline & $\begin{array}{l}\text { Butter. A share of samples not conforming to } \\
\text { SER (sanitary-chemical parameters) }\end{array}$ & 0.13 & 0.15 & 0.02 \\
\hline & $\begin{array}{l}\text { Fish. A share of samples not conforming to } \\
\text { SER (sanitary-chemical parameters) }\end{array}$ & 0.08 & 0.12 & 0.06 \\
\hline & $\begin{array}{l}\text { Bread and confectionary. A share of samples } \\
\text { not conforming to SER (sanitary-chemical } \\
\text { parameters) }\end{array}$ & 0.07 & 0.07 & 0.05 \\
\hline & $\begin{array}{l}\text { Culinary products. A share of samples not } \\
\text { conforming to SER (sanitary-chemical pa- } \\
\text { rameters) }\end{array}$ & 0.05 & 0.04 & 0.03 \\
\hline
\end{tabular}


Social and epidemiologic determinants and potential for growth in life expectancy of the population...

\begin{tabular}{|c|c|c|c|c|}
\hline $\begin{array}{l}\text { A group } \\
\text { of parameters }\end{array}$ & Parameter & $\begin{array}{c}\text { An increase in } \\
\text { LEB (overall } \\
\text { population), } \\
\text { days }\end{array}$ & $\begin{array}{c}\text { An increase } \\
\text { in LEB (male } \\
\text { population), } \\
\text { days }\end{array}$ & $\begin{array}{c}\text { An increase } \\
\text { in LEB } \\
\text { (female popula- } \\
\text { tion), days }\end{array}$ \\
\hline & $\begin{array}{l}\text { Milk. A share of samples not conforming to } \\
\text { SER (sanitary-chemical parameters) }\end{array}$ & 0.04 & 0.04 & 0.99 \\
\hline & $\begin{array}{l}\text { Meat. A share of samples not conforming to } \\
\text { SER (sanitary-chemical parameters) }\end{array}$ & 0.03 & 0.03 & 0.02 \\
\hline & $\begin{array}{l}\text { Poultry. A share of samples not conforming to } \\
\text { SER (sanitary-chemical parameters) }\end{array}$ & 0.02 & 0.01 & 0.88 \\
\hline & $\begin{array}{l}\text { Fish. A share of samples not conforming to } \\
\text { SER (microbiological parameters) }\end{array}$ & 0.003 & - & - \\
\hline & $\begin{array}{l}\text { All food products. A share of samples not } \\
\text { conforming to standards (calorie contents and } \\
\text { chemical structure) }\end{array}$ & - & - & 1.24 \\
\hline & $\begin{array}{l}\text { Meat. A share of samples not conforming to } \\
\text { SER (sanitary-chemical parameters) }\end{array}$ & - & - & 0.02 \\
\hline \multirow{2}{*}{$\begin{array}{c}\text { Sanitary-hygienic } \\
\text { properties of } \\
\text { objects }\end{array}$} & $\begin{array}{l}\text { A share of objects belonging to the } 1^{\text {st }} \text { hazard } \\
\text { category }\end{array}$ & 12.28 & 2.59 & 20.20 \\
\hline & $\begin{array}{l}\text { A share of objects belonging to the } 3^{\text {rd }} \text { hazard } \\
\text { category }\end{array}$ & 2.88 & 1.46 & 4.17 \\
\hline \multirow{4}{*}{$\begin{array}{l}\text { Quality of air in } \\
\text { working areas } \\
\text { (taken in total at all } \\
\text { economic entities) }\end{array}$} & $\begin{array}{l}\text { A share of air samples with vapor and gases } \\
\text { contents exceeding MPC }\end{array}$ & 1.91 & 2.71 & 0.81 \\
\hline & $\begin{array}{l}\text { A share of air samples with contents of sub- } \\
\text { stances belonging to the } 1^{\text {st }} \text { and } 2^{\text {nd }} \text { hazard } \\
\text { category exceeding MPC (dusts and aerosols) }\end{array}$ & 1.8 & 1.72 & 1.87 \\
\hline & $\begin{array}{l}\text { A share of air samples with dusts and aerosols } \\
\text { contents exceeding MPC }\end{array}$ & 1.45 & 1.46 & 1.20 \\
\hline & $\begin{array}{l}\text { A share of air samples with contents of sub- } \\
\text { stances belonging to the } 1^{\text {st }} \text { and } 2^{\text {nd }} \text { hazard } \\
\text { category exceeding MPC (vapor and gases) }\end{array}$ & 1.19 & 1.71 & - \\
\hline \multirow{6}{*}{$\begin{array}{l}\text { Physical factors } \\
\text { at workplaces }\end{array}$} & $\begin{array}{l}\text { A share of workplaces not conforming to } \\
\text { sanitary standards (ILLUMINATION) }\end{array}$ & 16.22 & 17.74 & 14.59 \\
\hline & $\begin{array}{l}\text { A share of workplaces not conforming to } \\
\text { sanitary standards (NOISE) }\end{array}$ & 8.24 & 10.14 & 5.28 \\
\hline & $\begin{array}{l}\text { A share of workplaces not conforming to } \\
\text { sanitary standards (MICROCLIMATE) }\end{array}$ & 7.09 & 7.16 & 6.49 \\
\hline & $\begin{array}{l}\text { A share of workplaces not conforming to } \\
\text { sanitary standards (EMF) }\end{array}$ & 2.06 & 3.67 & - \\
\hline & $\begin{array}{l}\text { A share of workplaces not conforming to } \\
\text { sanitary standards (IR) }\end{array}$ & 1.24 & 1.40 & 1.01 \\
\hline & $\begin{array}{l}\text { A share of workplaces not conforming to } \\
\text { sanitary standards (VIBRATION) }\end{array}$ & 0.98 & 0.29 & 1.44 \\
\hline & Total & 140,39 & 146.9 & 117.62 \\
\hline
\end{tabular}

Note: * - SER means sanitary-epidemiologic requirements.

Prediction assessment revealed that an increase in a share of population provided with qualitative drinking water would make the highest contribution into a growth in life expectancy at birth (61.65 days). Better conditions at workplaces as regards physical factors can result in LEB among overall population growing by 35.83 days (Table, Figure 2 ).
A decrease in a share of object belonging to the $3^{\text {rd }}$ hazard category as per their sanitaryhygienic properties is substantial as an improvement in this parameter can lead to LEB among the overall population growing by 15.16 days. A decrease in a share of air samples with contaminants contents exceeding MPC in urban and rural settlements can result 
in LEB among the overall population growing by 14.26 days. An increase in quality of air in working areas can lead to LEB among the overall population growing by 6.35 days. Should there be a $10.0 \%$ decrease in a share of soil samples not conforming to standards as per sanitary-chemical parameters, LEB among the overall population would grow by 5.82 days. A small increase (1.32 days) could results from better quality and safety of food products.

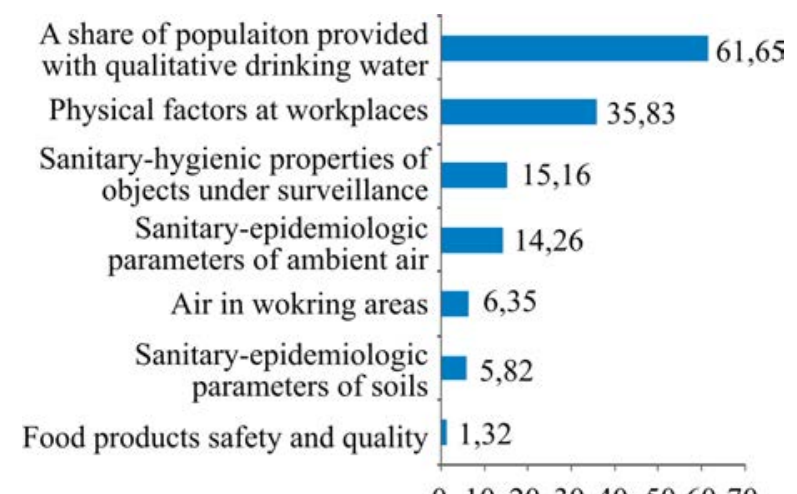

Figure 2. Predicted growth in life expectancy among the overall RF population determined by changes in sanitary-epidemiologic parameters in some groups (a scenario entails $10.0 \%$ improvement in the given parameters), days

Results which we obtained in the present research work justify the hypothesis on sanitary-epidemiologic environmental factors exerting their impacts on LEB and don't contradict data available in foreign and domestic research works on negative effects produced on population health by environmental factors deviating from sanitary standards [38-41]. An increase in a share of population provided with qualitative drinking water makes the greatest contribution into LEB growth (61.65 days for the overall population) and it is fully in line with data taken from the state reports "On Sanitary-epideiologic welfare of the population in the Russian Federation" according to which poor quality of drinking water results in up to 1.8 million additional disease cases among the overall RF population (55-60\% of all the additional environmentally induced diseases).
The next significant parameter that can lead to additional 35.83 days in LEB for the overall population is physical factors at workplaces. Our data are consistent with the data taken from the state report ${ }^{11}$ which indicate that physical environmental factors (noise, EMF, vibration, illumination, and IR) make the greatest contribution into death cases caused by circulatory system diseases and account for up to 52 housand additional death cases.

Improved sanitary-epidemiologic situation with ambient air in settlements can lead to 14.26 days increase in LEB for the overall population and it is also consistent with the data taken from the state report ${ }^{11}$ which indicate that in 2018 up to 864,000 additional disease cases (circulatory system diseases, respiratory organs diseases etc.) were caused by ambient air being contaminated with hazardous chemicals.

It is necessary to implement a set of measures that are aimed at reducing impacts exerted by hazardous factors on the environment and providing safe living conditions for people; it will allow a substantial contribution into achieving national goals and solving strategic tasks of the RF development. Thus, activities performed by Rospotrebnadzor and aimed at reducing contamination of environmental objects annually prevent more than 150 additional death cases and more than 7 million disease cases among the RF population ${ }^{11}$.

Conclusions. Our research results allowed us to make the following conclusions:

- should there be an improvement in analyzed sanitary-epidemiologic parameters, an overall increase in life expectancy at birth for the RF population can amount to 140.39 days;

- the most significant parameters that can potentially increase LEB for the overall RF population are the following: "A share of population provided with qualitative drinking water" (61.65 days); "Physical factors at workplaces" (35.83 days); "Sanitary-hygienic properties of surveillance objects" (15.16 days); and "Sanitary-epidemiologic parameters of ambient air" (14.26 days);

\footnotetext{
${ }^{11}$ On sanitary-epidemiologic welfare of the population in the Russian Federation in 2018: the State Report. Moscow, The Federal Service for Surveillance over Consumer Rights Protection and Human Well-being Publ., 2019, 254 p.
} 
- LEB was also analyzed separately for both sexes, and it allowed revealing that improved sanitary-epidemiologic situation would results in greater growth in LEB among male population (by 146.9 days) than among female population (by 117.6 days);

- all the developed activities aimed at improving sanitary-epidemiologic parameters and, consequently, at increasing LEB should be differentiated according to a specific region where they are to be implemented. Thus, RF regions that are included into the $1^{\text {st }}$ cluster should pay greater attention to sanitaryepidemiologic parameters of soils in settlements; RF regions that are included into the $2^{\text {nd }}$ cluster, to quality and safety of certain food products (meat, milk, fish, and bread), and air in working areas at industrial enterprises. Sanitary-epidemiologic situation is not so favorable in RF regions included into the $3^{\text {rd }}$ cluster.
People living on these territories are potentially exposed to stronger effects produced by anthropogenic contamination; to improve the situation there, it is necessary to take complex inter-sectoral efforts, especially as regards providing people with qualitative drinking water and food products as well as creating favorable working conditions at workplaces. In order to preserve achieved levels of population health and LEB in all RF regions and increase them in future, it is advisable to continue implementing federal and regional programs aimed at providing sanitary-epidemiologic welfare and improving health of the population in the Russian Federation.

Funding. The research was not granted any financial support.

Conflict of interests. The authors declare there is no any conflict of interests.

\section{References}

1. Morozov E.N., Litvinov S.K., Zhirenkina E.N. About the concept for eradication of diseases. Epidemiologiya i infektsionnye bolezni, 2016, vol. 21, no. 2, pp. 68-73 (in Russian). DOI: 10.18821/1560-9529-2016-21-2-68-73

2. Nakatani H. Global Strategies for the Prevention and Control of Infectious Diseases and Non-Communicable Diseases. Journal of Epidemiology, 2016, vol. 26, no. 4, pp. 171-178. DOI: 10.2188/jea.JE20160010

3. Modig K., Andersson T., Vaupel J., Rau R., Ahlbom A. How long do centenarians survive? Life expectancy and maximum lifespan. Journal of Internal Medicine, 2017, vol. 282, no. 2, pp. 156-163. DOI: 10.1111 /joim.12627

4. Medford A., Vaupel J.W. Human lifespan records are not remarkable but their durations are. PLoS One, 2019, vol. 14, no. 14 (3), pp. e0212345. DOI: 10.1371/journal.pone.0212345

5. Vishnevskii A.G. Snizhenie smertnosti narushaet traditsiyu, ne vstrechaya osobogo soprotivleniya [A decrease in mortality breaks the tradition without meeting any specific resistance]. Demoskop Weekly, 2011, no. 473, pp. 1-26 (in Russian).

6. Bennett J.E., Stevens G.A., Mathers C.D., Bonita R., Rehm J., Kruk M.E., Riley L.M., Dain K. [et al.]. NCD Countdown 2030: worldwide trends in non-communicable disease mortality and progress towards Sustainable Development Goal target 3.4. The Lancet, 2018, vol. 22, no. 392, pp. 1072-1088. DOI: 10.1016/S0140-6736(18)31992-5

7. Wang R., Zheng X., Wang H., Shan Y. Emission drivers of cities at different industrialization phases in China. Journal of Environmental Management, 2019, vol. 250, pp. 109494. DOI: 10.1016/j.jenvman.2019.109494

8. Wang Q., Su M., Li R. Toward to economic growth without emission growth: The role of urbanization and industrialization in China and India. Journal of Cleaner Production, 2018, vol. 205, pp. 499-511. DOI: 10.1016/j.jclepro.2018.09.034

9. Danish, Zhang B., Wang B., Wang Z. Role of renewable energy and non-renewable energy consumption on EKC: Evidence from Pakistan. Journal of Cleaner Production, 2017, vol. 156, pp. 855-864. DOI: $10.1016 /$ j.jclepro.2017.03.203

10. $\mathrm{Xu}$ B., Lin B. How industrialization and urbanization process impacts on $\mathrm{CO}_{2}$ emissions in China: Evidence from nonparametric additive regression models. Energy Economics, 2015, vol. 48, pp. 188-202. DOI: 10.1016/j.eneco.2015.01.005 
11. Malov A.M., Lukovnikova L.V., Alikbaeva L.A., Yakubova I.Sh., Shchegolikhin D.K. The results of the monitoring of the mercury contamination within a megapolis. Gigiena $i$ sanitariya, 2018, vol. 97, no. 12, pp. 1189-1194 (in Russian). DOI: 10.18821/0016-9900-2018-97-12-1189-1194

12. Rakhmanin Yu.A., Levanchuk A.V., Kopytenkova O.I., Frolova N.M., Sazonova A.M. Determination of additional health risk due to pollutants in ambient air during operation of road-vehicles complex. Gigiena i sanitariya, 2018, vol. 97, no. 12, pp. 1171-1178 (in Russian). DOI: 10.18821/0016-99002018-97-12-1171-1178

13. Yaschenko S.G., Rybalko S.Yu., Shibanov S.E., Grigoriev O.A. Monitoring of electromagnetic situation of radio frequency range of the mobile communication and prevalence indices of diseases of the circulatory system in the adult population. Gigiena $i$ sanitariya, 2018, vol. 97, no. 12, pp. 1184-1188 (in Russian). DOI: 10.18821/0016-9900-2018-97-12-1184-1188

14. Zaitseva N.V., Onishchenko G.G., Popova A.Yu., Kleyn S.V., Kiryanov D.A., Glukhikh M.V. Social and economic determinants and potential for growth in life expectancy of the population in the Russian Federation taking into account regional differentiation. Health Risk Analysis, 2019, vol. 4, pp. 14-29 (in Russian). DOI: 10.21668/health.risk/2019.4.02.eng.

15. Wilkinson R., Marmot M. Social determinants of health: the solid facts 2 nd edition. WHO Library Cataloguing in Publication Data, 2004, 33 p.

16. Stringhini S., Carmeli C., Jokela M., Avendaño M., Muennig P., Guida F., Ricceri F., d'Errico A. [et al.]. Socioeconomic status and the $25 * 25$ risk factors as determinants of premature mortality: a multicohort study and meta-analysis of 1,7 million men and women. Lancet, 2017, vol. 25, no. 389, pp. 1229-1237. DOI: $10.1016 / \mathrm{S} 0140-6736$ (16) 32380-7

17. Macken-bach J.P., Valverde J.R., Bopp M., Brønnum-Hansen H., Deboosere P., Kalediene R., Kovács K., Leinsalu M. [et al.]. Determinants of inequalities in life expectancy: an international comparative study of eight risk factors. Lancet Public Health, 2019, vol. 4, no. 10, pp. 529-537. DOI: $10.1016 / \mathrm{S} 2468-2667(19) 30147-1$

18. Gang L., Zhang Y., Knibbe W.J., Liu W., Medema G., Van Der Meer W. Potential impacts of changing supply-water quality on drinking water distribution: A review. Water Research, 2017, vol. 1, no. 116, pp. 135-148. DOI: 10.1016/j.watres.2017.03.031

19. Schriks M., Heringa M.B., Kooi M.M.E., van der Kooi M.M., de Voogt P., van Wezel A.P. Toxicological relevance of emerging contaminants for drinking water quality. Water Research, 2010, vol. 44, no. 2 , pp. 461-476. DOI: 10.1016/j.watres.2009.08.023

20. Wasana H.M., Perera G.D., Gunawardena P.S., Fernando P.S., Bandara J. WHO water quality standards Vs Synergic effect(s) of fluoride, heavy metals and hardness in drinking water on kidney tissues. Scientific Reports, 2017, vol. 14, no. 7, pp. 42516. DOI: 10.1038/srep42516

21. Schullehner J., Hansen B., Thygesen M., Pedersen C.B., Sigsgaard T. Nitrate in drinking water and colorectal cancer risk: A nationwide population-based cohort study. International journal of cancer, 2018, vol. 1, no. 143, pp. 73-79. DOI: 10.1002/ijc.31306

22. Rubino F., Corona Y., Perez J.G.J., Smith C. Bacterial contamination of drinking water in Guadalajara, Mexico. International journal of environmental research and public health, 2018, vol. 27, no. 16 (1), pp. E67. DOI: 10.3390/ijerph16010067

23. Ambient air pollution. Global health Observatory (GHO) data. WHO. Available at: https://www.who.int/gho/phe/outdoor_air_pollution/en/ (20.01.2020).

24. Lelieveld J., Haines A., Pozzer A. Age-dependent health risk from ambient air pollution: a modeling and data analysis of childhood mortality in middle-income and low-income countries. The Lancet Planetary Health, 2018, vol. 2, no. 7, pp. e292-e300. DOI: 10.1016/S2542-5196(18)30147-5

25. Ambient air pollution: a global assessment of exposure and burden of diseases. WHO. Available at: https://www.who.int/phe/publications/air-pollution-global-assessment/en/ (20.01.2020).

26. Landrigan P.J., Fuller R., Acost N.J.R., Adeyi O., Arnold R., Basu N.N., Baldé A.B., Bertollini R. [et al.]. The Lancet Commission on pollution and health. The Lancet Commissions, 2018, vol. 3, № 391 (10119), pp. 462-512. DOI: 10.1016/S0140-6736(17)32345-0

27. Sarkodie S.A., Strezov V., Jiang Y., Evans T. Proximate determinants of particulate matter (PM 2.5) emission, mortality and life expectancy in Europe, Central Asia, Australia, Canada and the US. Science of the Total Environment, 2019, vol. 15, no. 683, pp. 489-497. DOI: 10.1016/j.scitotenv.2019.05.278

28. Grossman G., Krueger A. Economic growth and the environment. The Quarterly Journal of Economics, 1995, vol. 110, no. 2, pp. 353-377. DOI: 10.2307/2118443 
29. Hill T.D., Jorgenson A.K., Ore P., Clark B., Balistreri K.S. Air quality and life expectancy in the United States: An analysis of the moderating effect of income inequality. SSM - Population Health, 2019, vol. 7, no. 100346, pp. 1-7. DOI: 10.1016/j.ssmph.2018.100346

30. Brønnum-Hansen H., Bender A.M., Andersen Z.J., Sørensen J., Bønløkke J.H., Boshuizen H., Becker T., Diderichsen F., Loft S. Assessment of impact of traffic-related air pollution on morbidity and mortality in Copenhagen Municipality and the health gain of reduced exposure. Environment International, 2018, vol. 121, no. 1, pp. 973-980 (in Russian). DOI: 10.1016/j.envint.2018.09.050

31. Tel'nov V.I., Tret'yakov F.D., Okatenko P.V. The shorten life expectancy in workers in relation to different histological types of lung cancer and absorbed dose to lungs from plutonium-239. Gigiena $i$ sanitariya, 2018, vol. 97, no. 2, pp. 174-178 (in Russian). DOI: 10.18821/0016-9900-2018-97-2-174-178

32. Shirlina N.G., Stasenko V.L., Kolchin A.S., Antonov O.V., Obukhova T.M. Labor conditions as a factor of the risk of the occurrence of colorectal cancer. Gigiena i sanitariya, 2018, vol. 97, no. 2, pp. 156-160 (in Russian). DOI: 10.18821/0016-9900-2018-97-2-156-160

33. Meshchakova N.M., Dyakovich M.P., Shayakhmetov S.F., Lisetskaya L.G. Formation of risks for a health disaster in workers, exposed to mercury. Gigiena $i$ sanitariya, 2018, vol. 97, no. 10, pp. 945-950. DOI: 10.18821/0016-9900-2018-97-10-945-950 (in Russian)

34. Kopytenkova O.I., Tursunov Z.Sh., Levanchuk A.V., Mironenko O.V., Frolova N.M., Sazonova A.M. The hygienic assessment of the working environment in individual occupations in building organizations. Gigiena i sanitariya, 2018, vol. 97, no. 12, pp. 1203-1209 (in Russian). DOI: 10.18821/0016-9900-2018-97-12-1203-1209

35. Kurchevenko S.I., Boklazhenko E.V., Bodienkova G.M. Comparative analysis of the immune response of workers exposed to various production factors. Gigiena i sanitariya, 2018, vol. 97, no. 10, pp. 905-909 (in Russian). DOI: 10.18821/0016-9900-2018-97-10-905-909

36. Kuleshova M.V., Pankov V.A., Dyakovich M.P., Rukavishnikov V.S., Slivnitsyna N.V., Kazakova P.V., Bochkin G.V. The vibration disease in workers of the aircraft enterprise: factors of the formation, clinical manifestations, social-psychological features (dynamic following-up). Gigiena $i$ sanitariya, 2018, vol. 97, no. 10, pp. 915-920 (in Russian). DOI: 10.18821/0016-9900-2018-97-10-915-920

37. Natsional'nye proekty: klyuchevye tseli i ozhidaemye rezul'taty. Pravitel'stvo Rossii [National projects: key targets and expected results. The RF Government]. Available at: http:/government.ru/ projects/selection/741/35675/ (22.01.2020) (in Russian).

38. Dzhambov A.M., Dimitrova D.D. Heart Disease Attributed to Occupational Noise, Vibration and Other Co-Exposure: Self-reported Population-Based Survey among Bulgarian Workers. Medycyna pracy, 2016, vol. 67, no. 4, pp. 435-445. DOI: 10.13075/mp.5893.00437

39. Héritier H., Vienneau D., Foraster M., Eze I.C., Schaffner E., Thiesse L., Ruzdik F., Habermacher M. [et. al.]. Diurnal variability of transportation noise exposure and cardiovascular mortality: A nationwide cohort study from Switzerland. International Journal of Hygiene and Environmental Health, 2018, vol. 221, no. 3, pp. 556-563. DOI: 10.1016/j.ijheh.2018.02.005

40. Rybkin V.S., Bogdanov N.A., Chuikov Yu.S., Teplaya G.A. Heavy metals as a factor of possible environmentally caused illnesses in the Astrakhan region. Gigiena i sanitariya, 2014, vol. 93, no. 2, pp. 27-31 (in Russian).

41. Onishchenko G.G., Zaitseva N.V., May I.V., Shur P.Z., Popova A.Yu., Alekseev V.B., Dolgikh O.V., Zemlyanova M.A. [et al.]. Health risk analysis in the strategy of state social and economic development. Russian Academy of Sciences The Federal Service for Supervision in the Sphere of Consumer Rights and Individual Welfare Protection Federal Budget Science Institution Federal Research Center of Medical-Preventive Technologies of Public Health Risk Management Publ., Moscow, Perm, 2014, pp. 686 (in Russian).

Popova A.Yu., Zaitseva N.V., Onishchenko G.G., Kleyn S.V., Glukhikh M.V., Kamaltdinov M.R. Social and epidemiologic determinants and potential for growth in life expectancy of the population in the Russian Federation taking into account regional differentiation. Health Risk Analysis, 2020, no. 1, pp. 14-17. DOI: 10.21668/health.risk/2020.1.01.eng

Received: 03.02.2020

Accepted: 19.03 .2020

Published: 30.03.2020 